Irena Dimova

ORCID: 0000-0002-5750-1741

Univerzita Mateja Bela Banská Bystrica, Slovenská republika

\title{
Problém „mužského“ jazyka (na príklade básní Migleny Nikolčinej a Ireny Ivanovej) ${ }^{1}$
}

https://doi.org/10.34739/clit.2021.15.17

\author{
The problem of the „male“ language \\ (on works by Miglena Nikolchina and Irena Ivanova)
}

\begin{abstract}
The paper is devoted to the problem of the „male“ language which can be found in the works of two Bulgarian poets - Miglena Nikolchina and Irena Ivanova (better known by her pseudonym Rene Karabaš). The author associates them with the change that happens in literary criticism and the literary production itself after the 1990s. The author considers the synthesis of poetry and prose, poetry and theory as an intertextual „dialogue” through which is possible to analyze the texts of both poets. Thematically, the article focuses on the ways in which the woman gains "a right to have a voice“ rejecting her gender to take up the poet's word and on how man appears to be a "quotation" in their works.
\end{abstract}

Keywords: male language, gender, a right to have a voice, word, quotation

V bulharskej literárnej vede, ako aj v širšom kontexte európskeho literárneho myslenia, bola $\mathrm{v}$ centre kritického záujmu téma písania o ženských obrazoch v poézii písanej mužmi dlhšie obdobie, než idea hladania mužských obrazov v poézii písanej ženami². Príčiny sú jasne vysvetlitel’né zmenami, ktoré sa udiali v 60. a 70. rokoch minulého storočia po preniknutí feminizmu do akadémie s jeho výraznou orientáciou na literatúru. V prípadoch, kedy sa do popredia posúva tzv. ženská otázka, aktuálne zostáva pýtanie sa na miesto literárnej produkcie autoriek $\mathrm{v}$ rámci

\footnotetext{
1 Štúdia je výsledkom riešenia projektu Vedeckej grantovej agentúry Ministerstva školstva Slovenskej republiky a Slovenskej akadémie vied číslo 1/0747/18 (Obrazy sveta ako výskumná doména humanitných vied. Produkcia, distribúcia, recepcia a spracovávanie obrazov sveta).

${ }^{2} \mathrm{~V}$ tejto línii sú obzvlášt prínosné knihy Mileny Kirovej, ako aj Migleny Nikolčinej, ktorej poézii sa tu venujeme.
} 
literárneho kánonu³, v ktorom spravidla prevládajú diela mužských autorov. V 90. rokoch sa záujem presmeroval, tentokrát k otázkam priestoru básne. Pozornost' sa začína venovat' jazyku a spôsobom jeho využitia u autorky, čím sa diskurz skutočne dostáva do vnútrotextových štruktúr. Na druhej strane sa spôsob prítomnosti muža v textoch písaných ženami stále akcentoval akoby iba reminiscenčne, až po prebraní všetkých diskurzov o druhu ženskej prítomnosti v textoch písaných aj mužmi, aj ženami. Rodové myslenie získava nové kontúry s preniknutím postmoderných tendencií do literárnej vedy - v našom prípade je dôležitá línia, ktorú označujeme ako teoretickobásnickú a vysvetlujeme ju podrobnejšie v súvislosti s Juliou Kristevovou d’alej v článku. Zmenu, ktorá nastáva v literárnej kritike a v literárnej produkcii autoriek od 90. rokov 20. storočia, ilustrujeme na príklade básnických textov dvoch bulharských poetiek - Migleny Nikolčinej a Ireny Ivanovej (pseudonymom Rene Karabaš).

\section{Prelúdium do heterogénneho diskurzu tvorby}

Slovo, ktoré používame na označenie svojrázneho úvodu, ktorý si diskurz o vybraných autorkách vyžaduje, nie je náhodné. Po prvé, Miglena Nikolčina a Irena Ivanova nie sú len poetky a spisovatel'ky, ale Nikolčina je aj literárnou kritičkou, teoretičkou a univerzitnou profesorkou, kým Ivanova je režisérkou, scenáristkou a herečkou. Po druhé, obe narábajú s jazykom reflexívne, spochybňujúc samotné slovo. Poetické a teoretické sa u nich (obzvlášt' u Migleny Nikolčinej) prelínajú do takej miery, že sa analytik ich tvorby mimovolne adaptuje $\mathrm{k}$ nimi vytvorenému druhu heterogénneho diskurzu.

Ak sa aj my nevedomky prispôsobíme jazyku poetiek, možno by sme mali začat’ písat’ o ich poézii jazykom samotnej poézie. Prijmúc hypotézu o syntéze prozaického a básnického jazyka, ktorú si dovol’ujeme aplikovat' na umeleckom diskurze vytvorenom tvorbou Ireny Ivanovej, sa v článku pozrieme na určité diela autorky cez ideu o prítomnosti intertextuálneho „dialógu“ v nich. Pôjde o jej román Ostajnica (2018) a jej básnické zbierky

\footnotetext{
3 Tu sa prikláňame k definícii kánonu podla Romana Mikuláša: „Kánon je záležitost’ výberu, hodnotenia, orientácie, redukcie istého nedefinovatel'ného (neštruktúrovaného) dynamického množstva na vymedzený priestor s orientačnými bodmi. Je to záležitost' tvorby konsenzu o kódovaní systému literatúry, o estetických kritériách, o hodnotnom a nehodnotnom, o závažnom a triviálnom, o príznakoch a kritériách. Hodnotenie tvorí akýsi rámec, v ktorom sa tvorba kánonu odohráva.“ R. Mikuláš, Kanón ako funkcia v autoreflexii systému literatúry, „World Literature Studies“ 2015, nr. 3, vol. 6, s. 65.
} 
Boky a motýle (2015) a Sesternica Zorbu (2020). Na druhej strane, u Migleny Nikolčinej je interferencia založená na komunikácii medzi jej básnickými a literárno-teoretickými textami. V tejto súvislosti považujeme za potrebné spomenút, že spomedzi literárno-kritických textov o jej tvorbe sú badatel'né dva prístupy reflektovania: jej teoretické práce sa na jednej strane spájajú s jej literárnou produkciou, na strane druhej pritom literárna kritika využíva metajazyk samotnej autorky4.

Diskurzy vytvárané týmto spôsobom svedčia o tom, že hovorit’ - a to hovorit’ obligatórne krásne - o poézii, je možné bud' jazykom samotnej poézie, alebo metajazykom literatúry. Modelovo slúži v tomto zmysle tvorba Migleny Nikolčinej, v ktorej sa stretávame s neustálymi reflexiami nad terminologickým aparátom literárnej vedy. Prirodzený inštinkt používat' jazyk teórie je viditelný v básnickej zbierke Mesto Amazoniek (2004), vktorej sa autorka vtexte s názvom Krátky úvod do asymbólie hrá s lexémou „asymbólia“ a jej konkrétnym stelesnením u Julie Kristevovej v zborníku Polylóg - ako „istý druh odstredivosti, asymetrickost’ oproti niečomu, alebo jednoducho strata symbolickosti, chápanej ako druhové členenie, význam, zmysel“ a ako „nepoddajnost’ a odmietnutie jazyka „vsat" ženu“.5 V krátkom esejistickom texte o „asymbólii“ sa problematizuje „mužskost“ jazyka, ktorá neprepúšta „sómu“ ženy. Do popredia sa tak dostáva posúva otázka, ako písat’ o ženskej poézii - a tým aj ženskú poéziu „mužským“ jazykom.

\section{Problém jazyka}

Ty, ktorý ma čítaš, si si istý, že rozumieš môjmu jazyku?6

Idea použitia a použitel'nosti (a tým aj možností) jazyka má množstvo realizácií v súvislosti s dobovým kontextom literatúry, do ktorého túto ideu situujeme. Hlavným činitel’om v zmene chápania práce so slovami sú premenlivé kontúry ako literatúry, tak aj myslenia literatúry či myslenia

\footnotetext{
4 Napr. К. Спасова, Обръщане към Темискира, „Литературен клуб” 2009, год. ХІІ, бр. 133, https://kamelia.litclub.bg/prisustvia.htm [dátum prístupu: 20.01.2021].

5 M. Nikolčina, Krátky úvod do asymbólie, „Dotyky“ roč. XXXI, č. o6, s. 6o. Uplatnenie pojmu „asymbólia“ u Migleny Nikolčinej spája Milena Kirova so symbolom ,jedného zápasu o sebe, zápasu o práve na ženskost', jedného hl’adania „ženských“ základov v mytologickom vynájdení schopnosti byt' (patriarchálne) civilizovaným“ alebo ešte ako „získanie ženského zmyslu kultúry a jazyka“. М. Кирова, Думи с/у думи. Постмодерният ерос, „Култура” 1999, бр. 10, http://www.online.bg/kultura/my_html/2070/dumi.htm [dátum prístupu: 20.01.2021].

${ }^{6}$ М. Николчина, Смисъл и майцеубийство, София 1997, с. 81.
} 
o literatúre. Variabilnost' jazykových realizácií vyplývajúcich zo spochybnenia jazyka sa stáva obzvlášt aktuálnou po roku 1989. Toto obdobie, známe aj ako tretia vlna feminizmu7, je úzko spojené s rolou spisovatel'ky ako intelektuálky a s jedným z jej prejavov - píšucej ženy. Preto sa u Migleny Nikolčinej vyskytuje otázka jazyka, ktorým sa píše o samotnom „ženskom písaní“. V súlade s Joan Scottovou, ktorá opisuje diskurz o francúzskom feminizme ako paradox, pretože sa píše jazykom práv mužov - ide o odkaz na francúzsky jazyk, v ktorom sa tým istým slovom označuje muž aj človek (un homme) ${ }^{8}$, - poetka píše svoje verše s jasným vedomím alogickosti jazyka. Hladanie autorky pokračuje v samotnom slove a v jeho túžbe po vlastnej sebestačnosti.

V stave podobného hl'adania je aj slovo Ireny Ivanovej. V jej textoch, básnických a beletristických, je problém „vyriešený“ dvoma spôsobmi: autorka sa prezentuje ako muž, alebo získava „právo písat“ z pozície ženy. Druhý príklad procesu „oprávnenia na slovo“ nachádzame v nasledujúcich veršoch zo zbierky Boky a motýle:
počula [som], že
dobré múzy nestoja
vedl'a svojich básnikov
zobrala som si diár a ceruzku
l'ahla som si na postel'
a začala čakat’ na šiesty deň 9

Funkcia sa degeneruje. Žena sa stáva autorom, tým že sa odrieka roly múzy a jej pasívnosti. Idea sa stelesňuje gestom vzatia atribútu písania. V centre básnického sveta stojí idea „získania“ práva hovorit’ z pozície ženy, teda písat’ a tým byt’ ženským autorom. Ďalej je realizácia tejto koncepcie spojená - v už menovanej debutovej knihe Boky a motýle - s ideou stat’ sa svojím vlastným bohom. Táto idea prechádza skrz metamorfózu, ktorá má za následok premenu ženy v muža. Hrdinka románu Ostajnica Bekia sa

\footnotetext{
7 Bulharská kritička Amelia Ličeva spája tretiu vlnu feminizmu s niekolkými líniami postmodernizmu, jednou zktorých je dekonštrukcia. Zároveň ide jednak o koncepciu marginálnosti, ako súčasti postmodernistických hl’adaní, jednak o jej antipód - vnímanie ženy ako centru, ako totalizujúcej osoby. А. Личева, Жената като другото. Балкански идентичности, https://balkansbg.eu/bg/content/b-identichnosti/134-zhenata-katodrugoto-evropejskiyat-kontekst.html [dátum prístupu: 20.01.2021].

${ }^{8}$ М. Николчина, Изгубените еднорози на революцията. Българските интелектуалци през 1980-те години, „Литературен вестник” 2012, с. 44.

9 Všetky preklady z bulharčiny do slovenčiny sú moje, I.D.
} 
takisto zrieka svojho ženského pohlavia, aby sa stala synom, ktorý sa iba narodil v tele dcéry, fetus in fetu ${ }^{10}$. Aby si sa stal človekom, ktorý sa narodil ženského pohlavia, musíš získat slovo, čo v jazyku a jazykom poézie Ireny Ivanovej neznamená iba stat’ sa vôbec, ale stat’ sa svojím vlastným kreátorom.

Bojan Minčev píše o jej poézii ako o „sebareflexii skúsenosti v jazyku“11. Táto sebareflexia sa skôr prejavuje na úrovni poetologickej, v tom, že sa verš rozštepuje, netoleruje interpunkciu a dovoluje si vizuálne medziveršové pauzy. Text Ireny Ivanovej vie odňat’ funkciu slovu a vymenit’ ho za jeho pokračovanie v deji. V texte s incipitom Opýtal som sa jej... sa slovo stelesňuje v činnost'. Žena je opýtaná na definíciu ako zomierajú vtáky, a namiesto slovesnej odpovede sa vyjadruje gestom. Jej príklad zostáva u muža (v tomto prípade - lyrického hovorcu) iba vo forme a realizácii slovesnej, aby fyzicky zostal a odovzdal odkaz ženy, ktorá mu ukázala život aj smrt' vtákov.

opýtal som sa jej

ako zomierajú vtáky

rozprestrela krídla

usmiala sa a skočila

nasledoval som ju

ale svoje som nerozprestrel

niekto mal

odvetit na tú otázku

U Ireny Ivanovej je čitatel’ná diferenciácia mužskej a ženskej roly, ktorá ruší nielen sociálne stereotypy, ale predovšetkým tie literárne. Funkcia autora, ktorý ako muž jednoduchoje a ako žena sa ním musí stat', je uložená v jej textoch na rozhraní jasne oddelených spoločenských a literárnych kontextov. Na mikrosituáciach, v ktorých sa každodennost’ stretáva vzájomne s umením, sú založené jej poetické mikrosvety. V nich má žena ako autorka vzţah k jazyku, ktorý často prerastá do (tichého) konfliktu.

U Migleny Nikolčinej sa dekonštrukcia jazyka uskutočňuje na úrovni sémantickej. Zmyslový nonsens prevláda, no nevylučuje veršové presahy

\footnotetext{
${ }^{10}$ Za tému svojho románu Ostajnica Irena Ivanova vyberá sujet zo severného Albánska, kde ked' muž v rodine zomrie a rod zostáva bez mužského dediča, musí sa nevydatá žena stat’ patriarchom - hlavou rodiny.

${ }^{11}$ I. Ivanova, Bulharská poetka Irena Ivanova, „Dotyky“ 2018, roč. XXX, č. 02, s. 50.
} 
a neočakávané cezúry. To, čo sme označili ako nonsens, má na druhej strane svoje opodstatnenie, dokonca teoretické vysvetlenie v literárnovedných textoch autorky. Preto sa čítanie jej poézie cez jej teoretické práce javí do určitej miery jediným spôsobom pokusu o interpretáciu jej tvorby. Nikolčinej metaliterárne texty svedčia o istom postupe, ktorý si autorka zvolila pri komponovaní svojich kritických reflexií. Za každým jej textom sa odzrkadl'uje vedomie „nepamäte, ktorá odsudzuje ženský hlas stále oznamovat’ svoj začiatok“12. Táto „nepamät“ indikuje situáciu „ženského hlasu“ ako situáciu kolektívneho problému jeho pozbavenosti. Povedané slovami Migleny Nikolčinej, nepamät’ vyplýva zo „zablokovania priestorovej a časovej vyčlenenosti, ktorá odsudzuje píšucu ženu, aby bola večne prvou zo svojho druhu“13. Preto v situácii, kedy slovo hladá svoju vlastnú sémantiku, žena hladá vlastnú podstatu slovami stratenými v označujúcich a označovaných tých istých slov.

Symbolickou je vtomto smere reflektovania jazyka skladba Predsymfónia hlasu. Lyrické Ja zakladá svoj monológ (postupne rozrastajúci sa do dialógu) na diáde mlčania - hlasnost'. V tomto texte Miglena Nikolčina vyvoláva figúru Sapfó, pričom asociácie k tejto starogréckej poetke, ako aj k bohyni Afrodite, sú typické pre jej zbierku Mesto Amazoniek:

Sapfó, nechcela si sa dotknút dlaňou neba, ale tvoje slová ho napriek tomu dosiahli.

Hlas lyrického Ja je tým, že je ženským hlasom, tautologicky bezhlasný. Preto sú slová hrdinky smerované iba knemým, ked’že sú bezzvučné:

Chcem iba onemených utísit',

že ak mám verné slovo, to je

ich rozkvitnuté mlčanie.

Chcem utíšit seba,

že zajtra v hrdlách mocnejších

rozkvitne

to, čo nevyslovím.

A nech vetry fučia,

nech spieva oceán.

${ }_{12}$ М. Николчина, Изгубените..., ор. cit., с. 93.

13 Ibidem, c. 118. 
V d’alšej básni z cyklu Záhrady Mesiaca hlavná hrdinka Kassandra nechce len získat' boha. Chce vystriedat funkcie a pozície, chce prevziat jeho slovo, ktoré je predovšetkým slovom mužským:

Čo mám prijat’ od Boha? A čo od l’udí?

Vravia,

že Kassandra neprijala do svojej postele svetlovlasého a spievajúceho boha, ale mu oddala

svoju dušu. Nie - povedala mu -

nedotýkaj sa ma, daj mi len

svoj jazyk, jazyk veštca, Phoebus, brat mesiaca,

vesmírne oko. Nechcem letmý dotyk,

chcem tvoje výhl'ady. A odmietla

si l'ahnút s ním.

...

Roztriasal ju svojím hlasom, áno,

žila nerestne so slovom.

Dnes prijíma božie telo,

hlas je jej.

Vo svete situovanom do mesta Amazoniek je erotika pochopitelne prisvojená ženským diskurzom. Preto sa lyrická hovorkyňa vzdáva mužského dotyku ako výrazu medzipohlavného vztahu, lebo sa tým odrieka samotnej idey intersexuálnosti a vyhlasuje monopol mužskej - u Migleny Nikolčinej androgýnnej - ženy. Erotika sa bezo zvyšku zmocňuje naratívu a vracia ho do jeho „,̌̌nských“ začiatkov, čo je u poetky spojené so „sebestačným pudom“ jazyka.

Stavanie, ktoré vykonáva „ženské slovo“, je označené ako „obrátená veža“, ktorá implikuje samozrejmý odkaz na Babylonskú vežu a u Migleny Nikolčinej následne na Borgesovu babylonskú knižnicu. Svojím pokusom vyslovit’ svet, žena buduje „obrátenú vežu“:

Obrátenú vežu som vybudovala, vo sne som sa prebudila, v čase, ktorý sa omámene vybral k svojim prameňom, živly šibú svoju azbuku, a každý jazyk sa roztrháva. 


\section{Teória, ktorá odmieta mužské idoly}

V tejto časti považujeme za potrebné pripomenút literárno-kritický vzt’ah Migleny Nikolčinej kjazyku. Vjej textoch o ženských figúrach západoeurópskej literatúry, ako o Julii Kristevovej alebo Virginii Woolfovej, autorka píše o jazyku u nich ako o jazyku „hladajúcom si telo“. Píše o „modlitbe jazyka“, ktorý potrebuje telo, lebo si hladá nové formy. Jeho želanie sa asociuje s túžbou morskej panny vraviacej: „Daj mi telo, matka urob ma nesmrtel'nou, aby som mohla lúbit'!"14. Základ teoretických hl'adaní Migleny Nikolčinej je zbavený mužských idolov, pretože autorka siaha prevažne po ženských teoretičkách. Vtedy, ked' sa rozhodne zahrnút mužské odkazy, sú tieto referencie asimilované sekundárne skrz ženské reflexie.

\section{Prítomnost’ muža ako ustálená citácia}

Intertextualita ako bezpochyby prínosná pre formovanie literárnovedeckého myslenia druhej polovice 20. storočia je jednou z hlavných línií kritických reflexií Migleny Nikolčinej. U bulharskej kritičky budí obrovský a - možno povedat' - oprávnený záujem práve figúra Julie Kristevovej, ktorej komplexnost' pochádza z dvojdomovosti, ba dokonca trojdomovosti intelektuálky opisujúcej samu seba ako ženu bulharského pôvodu, francúzskej národnosti, - $\mathrm{s}$ európskym občianstvom a adoptovanú Amerikou. Aj syntéza biografie a tvorivej biografie, aj samotná povaha kritického uvažovania autorky sa javia byt príčinou trvalého záujmu Migleny Nikolčinej o francúzsku teoretičku ${ }^{15}$.

Zhodné chápanie feminizmu je hlavným bodom spájajúcim obe spisovatel'ky. Koncepcia Julie Kristevovej spočíva v porozumení jedinečnosti každého jednotlivca, ktorý nie je diferencovaný ako muž alebo žena. Vrátiac sa k intertextualite, možno ju spojit’ s prejavmi feminizmu v textoch Migleny Nikolčinej. V poézii oboch analyzovaných autoriek sa mužské zvykne reprezentovat’ ako citácia. Vzhl’adom na ženský diskurz

\footnotetext{
${ }_{14}$ М. Николчина, Смисъл и майцеубийство, София 1997, с. 52.

${ }^{15} \mathrm{O}$ nej píšu aj mnohí iní literárni kritici a filozofi, ako Judith Butler (Gender Trouble: Feminism and the Subversion of Identity, 1990), Tina Chanter a Ewa Ziarek (Between Revolt and Melancholia: The Unstable Boundaries of Kristeva's Polis, 2005), David Crowfield (Body/Text in Julia Kristeva: Religiom, Women and Psychoamalysis, 1992), John Fletcher a Andrew Benjamin (Abjection, Melancholia and Love: The Work of Julia Kruisteva, 1990), Nancy Fraser, Sandra Lee Bartky, Kelly Oliver a d’alší.
} 
vytváraný umeleckým textom, Miglena Nikolčina spomína kalambúr Krasimiry Kruškovej „To, o čom sa nedá hovorit’, sa musí citovat" ${ }^{\text {“16 }}$.

Muž v tvorbe Migleny Nikolčinej je často prítomnostou, ktorá sa realizuje svojou vlastnou negáciou. Na muža sa odkazuje ako na celistvost', ktorá nepotrebuje analýzu. „Rozvrstvená“ žena privoláva osobu Atanasa Dalčeva, ktorý zaujíma zvláštnu pozíciu v „meste Amazoniek“. Básnik predstavuje bulharské mužské slovo, ktoré zostáva v paratexte knihy - na rozdiel od Hölderlina, ktorý sa dostáva aj do tkaniva textu. Obaja autori sú súčastou dvojitej citácie, dvojitého odkazu z paratextového priestoru básne Smútok za Dalčevom/Hölderlinom. Podobne sa vtextoch Migleny Nikolčinej stretávame s referenciami na d’alších autorov, napríklad Vergília, Danteho a bulharského Veličkova. Akoby ani autorka, ani jej lyrické hlasy nemali identitu. Preto sú v jej textoch vyvolaní predkovia - aby hovorili svojou pamätou, pretože oni predstavujú pamät’ a žena naopak vlastní „nepamät“ (ktorú sme vyššie spojili s neustálym návratom k začiatkom).

Opozičná dvojica pamät - nepamät sa u Ireny Ivanovej realizuje podobným spôsobom. Rozdiel je vtom, že je zdôraznená neznalost' mužských predkov, ktorú lyrická hrdinka nachádza u svojej ženskej predkyne. Tým sa aj samotné autorkino Ja rozhraničuje ako dedička nových idolov, a to predovšetkým ako dôkaz toho, že si novú pozíciu v mužskom svete písaného slova žena už získala.

Moja matka nevie nič o Freudovi

nevie kto je Osho

ani Krishnamurti

o Steinerovi povie

"je to šteňa“

nie je psychoterapeutka

ale vie presne kto je Boh

na moje otázky odpovedá stručne:

Ovoňaj kvet

prekopaj záhradu

otvor okná dokorán

a spievaj!

A slová zo všetkých kníh

v mojej knižnici miznú

ich biele strany vzlietajú

${ }^{16}$ Kalambúr Krasimiry Kruškovej o známom Wittgensteinovom vyjadrení „O čom nemožno hovorit, o tom treba mlčat“. К. Крушкова, Устните като кавички, София 1992, с. 95. 
nad mojou hlavou

a konečne zaspievam

skutočnú pieseň života

\section{Namiesto záveru androgýnny um}

Mužskost' ako citácia v textoch Migleny Nikolčinej je prítomné nielen ako jasný literárny odkaz alebo element paratextu. Mužský hlas sa stále implikuje ako pozadie ženského hlasu, aby sa stal súčastou jednou z oboch strán ženského umu - androgýnneho umu. Na konci svojej eseje Vlastná izba (1929) Virginia Woolf spomína básnika Samuela Coleridga v súvislosti s androgýnnym umom, aký je podl'a nej vel'ký um - dvojpohlavný. Podl’a autorky androgýnny um prenáša emócie bez prekážky a je prirodzene tvoriaci, oslepujúco žiarivý a nedelitel'ný17.

Práve takým je aj um, ktorý „píše“ poéziu nami vybraných a analyzovaných autoriek. U Ireny Ivanovej sa androgýnnost' stelesňuje, aby sa ruka „predlžujúca“ mysel’ tiež premenila na mužskú, ako napríklad u Bekie z románu Ostajnica. Androgýnnost' teoretického písania zas u Migleny Nikolčinej nachádza svoje pokračovanie v jej básnických textoch.

\section{Literatúra}

Ivanova I., Bulharská poetka Irena Ivanova, „Dotyky“ 2018, roč. XXX, č. 02, S. 50-53.

Mikuláš R., Kanón ako funkcia v autoreflexii systému literatúry, „World Literature Studies“ 2015, vol. 6, nr. 3, s. 63-75.

Nikolčina M., Krátky úvod do asymbólie, „Dotyky“ 2020, 2019, roč. XXXI, č. o6, s. 58-61.

Woolf V., A Room of One's Own, London 1993.

Карабаш Р., Хълбоци и пеперуди, София 2015.

Карабаш Р., Остайница, София 2018.

Карабаш Р., Братовчедката на Зорбас, София 2020.

Кирова М., Думи с/у думи. Постмодерният ерос, „Култура“ 1999, бр. 10, http://www.online.bg/kultura/my_html/2070/dumi.htm [dátum prístupu: 20.01.2121].

Крушкова К., Устните като кавички, [в:] Ars erotica, София 1992.

Личева А., Жената като другото, Балкански идентичности, https://balkansbg.eu/bg/content/b-identichnosti/134-zhenata-katodrugoto-evropejskiyat-kontekst.html [dátum prístupu: 20.01.2121].

Николчина М., Смисъл и майцеубийство, София 1997, с. 81.

Николчина М., Градът на амазонките, София 2008.

17 V. Woolf, Room of One's Own, London 1993, p. 89. 
Николчина, М., Изгубените еднорози на революцията. Българските интелектуалци през 1980-те години, София 2012.

Спасова, К., Обръщане към Темискира, „Литературен клуб“ 2009, бр. 133, год XII, https://kamelia.litclub.bg/prisustvia.htm [dátum prístupu: 20.01.2121].

\section{References}

Ivanova I., Bulharská poetka Irena Ivanova, „Dotyky“ 2018, roč. XXX, č. 02, S. 50-53.

Karabaš R., Bratovčedkata na Zorbas, Sofiâ 2020.

Karabaš R., H"lboci i peperudi, Sofiâ 2015.

Karabaš R., Ostajnica, Sofiâ 2018.

Kirova M., Dumi s/udumi. Postmoderniât eros, „Kultura“ 1999, br. 10, http://www.online.bg/kultura/my_html/2070/dumi.htm [datum pristupu 20.02.2021].

Kruškova K., Ustnite kato kavički, [v:] Ars erotica, Sofiâ 1992.

Ličeva A., Ženata kato drugoto, Balkanski identičnosti, https://balkansbg.eu/bg/content/b-identichnosti/134-zhenata-katodrugoto-evropejskiyat-kontekst.html [datum pristupu: 20.01.2021].

Mikuláš R., Kanón ako funkcia $v$ autoreflexii systému literatúry, „World Literature Studies“" 2015, vol. 6, nr. 3, s. 63-75.

Nikolčina M., Grad"t na amazonkite, Sofiâ 2008.

Nikolčina M., Krátky úvod do asymbólie, „Dotyky“ 2020, 2019, roč. XXXI, č. o6, s. 58-61.

Nikolčina M., Smis"l i majceubijstvo, Sofiâ 1997.

Nikolčina, M., Izgubenite ednorozi na revolûciâta. B"lgarskite intelektualci prez 1980-te godini, Sofiâ 2012.

Spasova, K., Obr"ŝane k"m Temiskira, „Literaturen klub“ 2009, br. 133, god. XII, https://kamelia.litclub.bg/prisustvia.htm [datum pristutpu: 20.01.2121].

Woolf V., A Room of One's Own, London 1993, p. 89. 